\title{
North American Rendering - processing high quality protein and fats for feed
}

\author{
David L. Meeker ${ }^{1}$
}

${ }^{1}$ National Renderers Association, Alexandria, VA.

ABSTRACT- One third to one half of each animal produced for meat, milk, eggs, and fiber is not consumed by humans. These raw materials are subjected to rendering processes resulting in many useful products. Meat and bone meal, meat meal, poultry meal, hydrolyzed feather meal, blood meal, fish meal, and animal fats are the primary products resulting from the rendering process. The most important and valuable use for these animal by-products is as feed ingredients for livestock, poultry, aquaculture, and companion animals. There are volumes of scientific references validating the nutritional qualities of these products, and there are no scientific reasons for altering the practice of feeding rendered products to animals. Government agencies regulate the processing of food and feed, and the rendering industry is scrutinized often. In addition, industry programs include good manufacturing practices, HACCP, Codes of Practice, and third-party certification. The rendering industry clearly understands its role in the safe and nutritious production of animal feed ingredients and has done it very effectively for over 100 years. The availability of rendered products for animal feeds in the future depends on regulation and the market. Regulatory agencies will determine whether certain raw materials can be used for animal feed. The National Renderers Association (NRA) supports the use of science as the basis for regulation while aesthetics, product specifications, and quality differences should be left to the market place. Without the rendering industry, the accumulation of unprocessed animal by-products would impede the meat industries and pose a serious potential hazard to animal and human health.

Key Words: feed, ingredients, manufacturing practices, rendering

\section{North American Rendering - processamento de proteínas e gorduras de alta qualidade para alimentos para animais}

RESUMO - De um terço a metade da produção animal para carne, leite, ovos e fibra, não são consumidos pelos seres humanos. Estes materiais não consumidos são sujeitos a processamento em graxarias e indústrias de alimentos de origem animal, resultando em uma série de produtos úteis. Entre estes produtos incluem-se farinha de carne e ossos, farinha de carne, farinha de co-produtos de abatedouros de aves, farinha hidrolisada de penas, farinha de sangue, farinha de peixe, e gorduras animais são os produtos primários resultantes dos processos de graxarias. O mais importante e valoroso uso para estes co-produtos de origem animal é a utilização como ingredientes alimentares para compor dietas e rações para bovinos, suínos, aves, peixes e animais de companhia. Há numerosas referências científicas validando as qualidades nutricionais destes produtos, e não há razões científicas para alterar a prática de uso destes co-produtos para os animais. As agências governamentais regulam o processamento de alimentos tanto para animais como para humanos, e a indústria de alimentos de origem animal é monitorada frequentemente. Além disso, os programas destas indústrias adotam as boas práticas de fabricação (PBF), HACCP, código de práticas, e as certificações. A indústria de alimentos de origem animal entende claramente seu papel na produção destes alimentos, de forme que sejam seguros e de alta qualidade nutricional, e tem feito isto de forma efetiva por mais de 100 anos. A disponibilidade de co-produtos de origem animal no futuro dependerá de regulação e do mercado. As agências regulatórias determinarão quais co-produtos poderão ser utilizados na produção de alimentos para animais. A Associação Nacional de Indústrias de Alimentos de Origem Animal (National Renderers Association, NRA) suporta o uso da ciência como base para a regulação, enquanto diferenças em relação à ética, especificação de produtos e qualidade, devem ser deixadas para o mercado local. Sem a indústria de alimento de origem animal, o acúmulo de co-produtos não processados impediria a indústria de carnes de se manter e traria um risco potencial sobre a saúde dos animais e dos seres humanos.

Palavras-chave: alimento para animais, graxaria, ingredientes, práticas de industrialização 


\section{Introduction}

\section{Raw material}

A by-product is defined as a secondary product obtained during the manufacture of a principal commodity. A co-product is a product that is usually manufactured together or sequentially with another item because of product or process similarities. Some prefer the more positive connotation of the term co-product, but for simplicity, this book will mostly use the term by-product. A portion of the profit returned to animal production and processing industries depends on the utilization of the byproducts or co-products ancillary to the production of meat, milk, and eggs for human food production. The FDA regulates which materials can be included in animal feed, and in 1997 banned the feeding of ruminant materials back to ruminant animals. Considerable debate has takenplace recently on whether more bovine materials should be banned from all animal feeds.

The approximately 250 rendering facilities in North America serve animal industries by utilizing the by-products which amount to more than half of the total volume produced by animal agriculture. The U.S. currently produces, slaughters, and processes approximately 100 million hogs, 35 million cattle, and eight billion chickens annually. Byproducts include hides, skins, hair, feathers, hoofs, horns, feet, heads, bones, toe nails, blood, organs, glands, intestines, muscle and fat tissues, shells, and whole carcasses. These by-product materials have been utilized for centuries for many significant uses. The products produced from the "inedible" (meaning not consumed by humans) raw material make important economic contributions to their allied industries and society. In addition, the rendering process and utilization of these byproducts contribute to improvements in environmental quality, animal health, and public health.

Approximately 49 percent of the live weight of cattle, 44 percent of the live weight of pigs, 37 percent of the live weight of broilers, and 57 percent of the live weight of most fish species are materials not consumed by humans. Some modern trends, such as pre-packed/table ready meat products, are increasing the raw material quantities for rendering. The current volume of raw material generated is nearly 54 billion pounds annually. Rendering raw materials vary, but an overall approximation of content would be 60 percent water, 20 percent protein and mineral, and 20 percent fat. These organic materials are highly perishable and laden with microorganisms, many of which are pathogenic to both humans and animals. Rendering offers a safe and integrated system of animal raw material handling and processing that complies with all of the fundamental requirements of environmental quality and disease control.

The Rendering Process-Rendering is a process of both physical and chemical transformation using a variety of equipment and processes. All of the rendering processes involve the application of heat, the extraction of moisture, and the separation of fat. The methods to accomplish this are schematically illustrated in Figure 1 (Hamilton, 2004).

The temperature and length of time of the cooking process are critical and are the primary determinant of the quality of the finished product. The processes vary according to the raw material composition.

All rendering system technologies include the collection and sanitary transport of raw material to a facility where it is ground into a consistent particle size and conveyed to a cooking vessel, either continuous-flow or batch configuration. Cooking is generally accomplished with steam at temperatures of $240^{\circ}$ to $290^{\circ} \mathrm{F}$ (approximately $115^{\circ}$ to $145^{\circ} \mathrm{C}$ ) for 40 to 90 minutes depending upon the type of system and materials. Most North American rendering systems are continuous-flow units. Regardless of the type of cooking, the melted fat is separated from the protein and bone solids and a large portion of the moisture is removed. Most importantly, cooking inactivates bacteria, viruses, protozoa, and parasites. Alternative methods of raw material disposal such as burial, composting, or landfill applications do not routinely achieve inactivation of microorganisms.

Fat is separated from the cooked material via a screwpress within a closed vessel. Following the cooking and fat separation, the "cracklings" or "crax," which includes protein, minerals, and some residual fat, are then further processed by additional moisture removal and grinding, then transferred for storage or shipment. Storage of the protein is either in feed bin structures or enclosed buildings. The fat is stored and transported in tanks.

Processes and technology of rendering have changed over the years and continue to improve. Modern rendering facilities are constructed to separate raw material handling from the processing and storage areas.

Process control is performed and monitored via computer technology so that time/temperature recordings for appropriate thermal death values for specific microorganisms are achieved. Temperatures far in excess of the thermal death time requirements are unnecessary and avoided because they can lower nutritional values and digestibility. Processes inNorth Americagenerally do not incorporate cooking under pressure except for feathers and other high keratin containing tissues. 


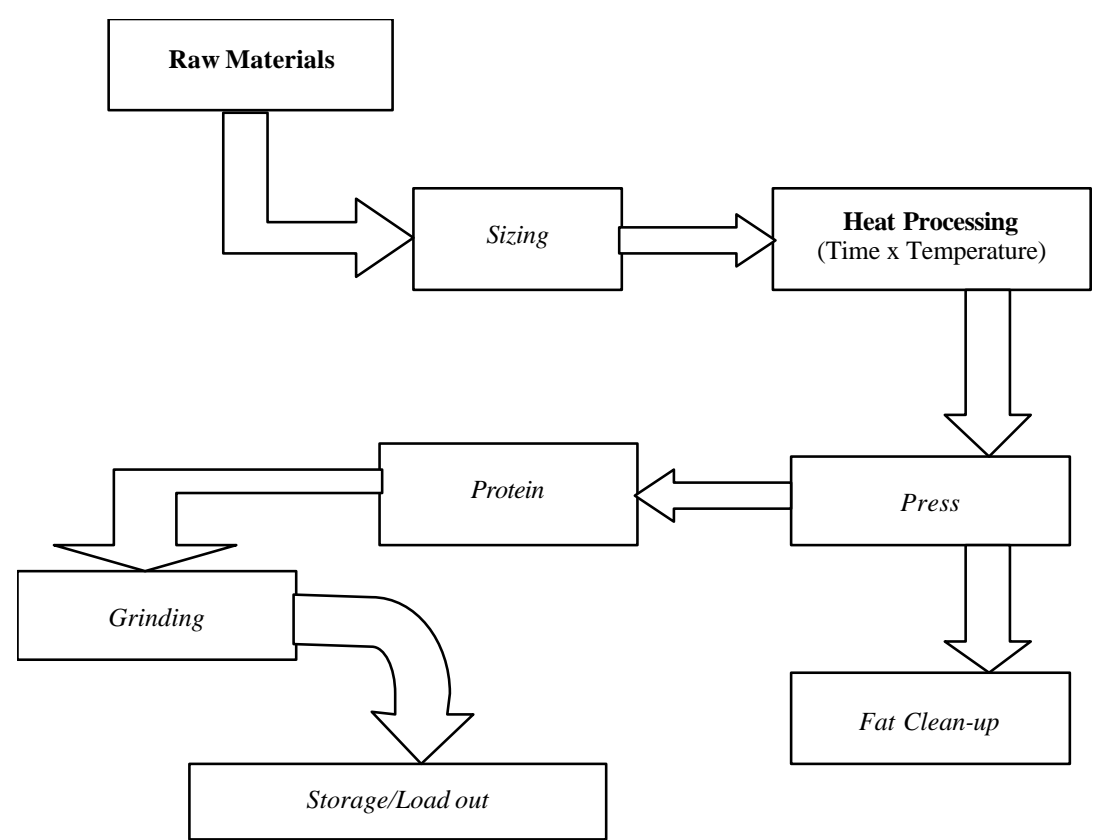

Figure 1 - The basic production process of rendering.

Research has demonstrated that raw material derived from food animal processing is heavily laden with microorganisms. Data illustrating the high incidence of food borne pathogenic microorganisms within raw animal by-product material and the efficacy of the rendering process in killing these pathogens are listed in Table 1.

It is now recognized that handling of ingredients after the cooking process can be responsible for recontamination-a concern for all feed ingredients and not restricted to animal protein. Salmonella is a bacteria species that is commonly associated with feed and often wrongly suspected of originating from the animal by-product ingredients. Data from around the world illustrate that all feed ingredients including vegetable proteins and grain may contain Salmonella (Beumer and Van der Poel, 1997; Sreenivas, 1998; McChesney et al., 1995; European Commission, 2003). Thus, it is important to follow industry feed safety guidelines or codes of practice in both pre-and post-handling of ingredients and manufactured feed.

Though research has demonstrated that rendering lowers the infectivity of the prion, the agent most commonly believed to be the cause of the transmissible spongiform encephalopathies (TSEs), it is not totally inactivated with any of the currently available rendering processes (Taylor, et al., 1995). This is why the FDA requires that raw materials containing ruminant by-products not be used to make ingredients used in ruminant feed.

The North American rendering industry recognizes its role in ensuring food safety and in protecting human and
Table 1 - Efficacy of the U.S. rendering system in the destruction of pathogenic bacteria

\begin{tabular}{lcc}
\hline Pathogen & $\begin{array}{c}\text { Raw tissue } \\
\text { \% samples positive }\end{array}$ & $\begin{array}{c}\text { Post process } \\
\text { samples positive }\end{array}$ \\
\hline Clostridium perfringens & 71.4 & 0 \\
Listeria spp. & 76.2 & 0 \\
L. monocytogenes & 8.3 & 0 \\
Campylobacter spp. & 29.8 & 0 \\
C. jejuni & 20.0 & 0 \\
Salmonella spp. & 84.5 & 0 \\
\hline
\end{tabular}

Source: Troutt et al. (2001) Samples from 17 different rendering facilities taken during the winter and summer.

animal health and has developed programs for biosecurity, Salmonella reduction, and third-party certification for compliance to feed regulations. In addition, North American rendering companies have adopted a Code of Practice-a voluntary Hazard Analysis and Critical Control Point (HACCP) based program.

Rendered animal by-products-The rendering process converts raw animal tissue into various protein, fat, and mineral products-rich granular-type meals and liquid fats with specific nutritional components. Annual volume in the U.S. is approximately 11.2 billion pounds of animal derived proteins and 10.8 billion pounds of rendered fats. About 85 percent of this production is utilized as animal feed ingredients. Industrial use applications in chemical, metallurgy, rubber, and oleochemical are the second largest utilization, with over 3,000 modern industrial use applications being identified. The manufacture of soaps 
and personal care products remain a major use for animal fats, especially tallow, and newer uses as biofuels are increasing on an annual basis.

Animal fats and recycled greases-Fats are the highest caloric-dense feed ingredient available. The animal feed and ingredient industry is a major user of rendered animal fats and recycled restaurant and cooking oils. In addition, fats and certain of their component fatty acids provide for essential and indispensable body functions separate from their caloric function. Including the recycled vegetable oils from restaurants, the rendering industry processes some 10.8 billion pounds annually of fats, detailed in Table 2 . The term lipid includes both fats and oils. Lipids are chemically structured primarily as triglycerides - a structure consisting of one unit of glycerol and three units of fatty acid. The fatty acids are the components that give the respective fats their individual chemical and physical characteristics. Most fatty acids found in natural fats vary in chain lengths from eight to 24 carbons. Feeding fats contain mostly fatty acids of 14 to 18 carbon lengths. If fatty acids have within their chemical structure double bonds, they are considered unsaturated. Structures without double bonds are saturated fatty acids. If more than two double bonds are present in the structure, fatty acids are referred to as polyunsaturated. As a carbon chain contains more saturated fatty acids, the melting point increases, and their physical nature are referred to as "harder fats." A measure of hardness is titre, determined by the solidification point of the fatty acids. Iodine value (IV) is another measurement of hardness/softness with unsaturated fats having higher IV values than saturated fats. Table 3 provides a guide of various animal fats comparing titre and IV.

Feed grade fats are often stabilized blends of animal and vegetable fats. They are produced by rendering the tissues of mammals and/or poultry and through recycling cooking oils. Feed fats consist predominately of triglyceride of fatty acids and contain no added free fatty acids (FFA) (National Renderers Association, 2003).

Products bearing a name descriptive of its kind or species origin must correspond thereto as beef, pork, or poultry. Poultry fat consists of fats derived from 100 percent poultry offal. Blended feed fatis a category that includes blends of tallow, grease, poultry fat, and restaurant grease/cooking oils. Blended animal and vegetable fats include blends of feed grade animal fats, poultry fats, vegetable fats, and/or restaurant grease/ cooking oil. It may also include by-products such as soap stock. Fats within this category are often referenced as animal/vegetable blends.
Table 2 - Fats produced by the U.S. rendering industry annually (billion pounds)

\begin{tabular}{ll}
\hline Edible tallow & 1.813 \\
Inedible tallow & 3.877 \\
Lard & 0.267 \\
Yellow grease & 1.472 \\
Other grease & 1.209 \\
Poultry fat & 1.181 \\
Total & 9.819
\end{tabular}

Source: U.S. Census Bureau Current Industrial Report M311K, 2005.

Note: Fats used in pet foods (approximately 1.0 billion pounds) are not included in above statistics.

Table 3 - Titre and iodine values for fat from various livestock

\begin{tabular}{lcr}
\hline Specie & \multicolumn{1}{c}{ Titre } & Iodine value \\
\hline Sheep & $44-48^{\circ} \mathrm{C}\left(111-118^{\circ} \mathrm{F}\right)$ & $42-43$ \\
Cattle & $42-45^{\circ} \mathrm{C}\left(108-113^{\circ} \mathrm{F}\right)$ & $43-45$ \\
Hogs & $36-40^{\circ} \mathrm{C}\left(97-104^{\circ} \mathrm{F}\right)$ & $63-65$ \\
Horses & $35-38^{\circ} \mathrm{C}\left(95-100^{\circ} \mathrm{F}\right)$ & $80-85$ \\
Poultry & $31-35^{\circ} \mathrm{C}\left(89-95^{\circ} \mathrm{F}\right)$ & $77-80$ \\
\hline
\end{tabular}

Source: Fats and Proteins Research Foundation Directors Digest \#269.

Though specifications are clearly defined and guarantees specified under several references, including the American Association of Feed Control Officials (AAFCO), suppliers of feeding fats can provide products that are labeled and guaranteed outside the trading standards. Suggestions for quality specifications for animal feed fats are listed in Table 4.

As with any feed ingredient, specifications should be thoroughly understood between supplier and purchaser. The following are common feeding fat guidelines: 1) Fats should be stabilized with an acceptable feed or food grade antioxidant added at levels recommended by the manufacturer. Stability tests can be performed to monitor. 2) No cottonseed soap stock or other cottonseed byproducts should be included in fats for layer, breeder, or broiler rations. 3) Fats must be certified that any PCB and pesticide residues are within the allowable limits established by state and/or federal agencies. 4) The supplier should make every effort to provide a uniform fat structure in each delivery. A specification for minimum and/or maximum IV can be established for the type of fat purchased. Monitoring IV s can determine if the product's fat structure is uniform.

Fat terminology - Total fatty acids_(TFA) include both the free fatty acids and those combined with glycerol (intact glycerides). Fat is composed of approximately 90 percent fatty acids and 10 percent glycerol. Glycerol contains about 4.32 calories per gram compared with 9.4 calories for fatty acids. Since fatty acids contain over 
Table 4 - Suggested quality specifications for feed fats

\begin{tabular}{lcccccc}
\hline & \multicolumn{5}{c}{ Blended fat categories } \\
\cline { 2 - 7 } & $\%$ & Animal & Poultry & Feed grade animal & Animal/Vegetable & Vegetable soap stock \\
\hline Total fatty acids & min. & 90 & 90 & 90 & 90 & 90 \\
Free fatty acids & max. & 15 & 15 & 15 & $158^{*}$ & 50 \\
Moisture & max. & 1 & 1 & 0.5 & 0.5 & 1.5 \\
Impurities & max. & 0.5 & 0.5 & 1 & $1.0^{*}$ & 1 \\
Unsponifiable & max. & 1 & 1 & 2 & 2 & 4 \\
Total MIU & max. & 2 & 2 & & & 6 \\
\hline
\end{tabular}

MIU = moisture, impurities, and unsaponifiables.

* When blended feed fats contain acidulated soap stock, this specification can be adjusted to allow higher free fatty acids found in this fat (i.e., five FFA per 10 percent added). Blended fats containing soap stock may also have higher unsaponifiable levels.

twice the energy of glycerol, the TFA content in fat acts as one indicator of energy.

One measure of fat quality is the FFA content. Fats are normally composed of three fatty acids linked to gylycerlol via ester bonds. FFA are produced when those fatty acids are freed by hydrolysis. Therefore, the presence of high levels of FFA indicates the fat was exposed to water, acids, and/or enzymes. Fats should be processed to contain as low a moisture level as feasible so that hydrolysis does not occur during storage.

Insoluble impurities usually consist of small particles of fiber, hair, hide, bone, or soil. These are insoluble in kerosene ether and can cause clogging problems in fat handling screens, nozzles, and other equipment, and contribute to the build-up of sludge in fat storage tanks.

Moisture is detrimental in fats since it accelerates corrosion of fat handling equipment and may increase rancidity resulting from formation of rust, which is a powerful promoter of rancidity. Moisture also contributes no energy, lubricity, or other benefits to feed and should be kept to a minimum. Moisture settles in fat making accurate sampling difficult.

Saponification Value (SV) is an estimate of the mean molecular weight of the constituent fatty acids in a fat sample and is defined as the number of milligrams of potassium hydroxide required to saponify one gram of the fat. Higher SV indicate lower mean chain lengths of the triglycerides.

Unsaponifiable fats contain a number of compounds such as sterols, hydrocarbons, pigments, fatty alcohols, and vitamins, which are not hydrolyzed by the alkaline saponification. Normal unsaponifiables have unknown and variable feeding values comparable to the fats involved and can dilute the energy content.

Iodine Value (IV): Each double bond in a fatty acid will take up to two atoms of iodine. By reacting fatty acids with iodine, it is possible to determine the degree of unsaturation of the fat or oil. The IV is defined as grams of iodine absorbed by 100 grams of fat. Unsaturated fats naturally have higher IVs than saturated fats so IV can be used to estimate complete fat structures.

Titre value is determined by melting the fatty acids after a fat has been hydrolyzed. The fatty acids are slowly cooled and the congealing temperature in degrees Centigrade is the titre. Animal fats are referred to as "tallow" if they possess a titre of 40 or higher, and are considered "grease" if the titre is below 40, regardless of the animal origin. Many buyers erroneously consider these terms as meaning beef or pork fats.

Fat color varies from the pure white of refined beef tallow, to the yellow of grease and poultry fat, to the very dark color of acidulated soap stock. Color does not affect the nutritional value of fat but may be a consideration in pet foods and other consumer oriented products.

Fat stability and antioxidants: To prevent the development of oxidative rancidity, which can destroy vitamins A, D, and E and cause other problems in feeds, antioxidants are recommended for all feed fats. Two main tests are used to measure stability of fats: 1)Peroxide Value (PV) - This test measures the milliequivalents (me) of peroxide per kilogram $(/ \mathrm{kg})$ and reveals the current state of oxidative rancidity. A low PV (sometimes defined as less than 10.0 me peroxide/kg.) indicates a non-rancid sample; 2) Active Oxygen Method (AOM) Test for 20 hour stability This is a measure of the peroxide value after 20 hours of bubbling air through the sample. This test is intended to determine the ability of the fat to resist oxidative rancidity in storage.

Tallow is primarily derived from rendered beef tissue but could contain other animal fat. Most chemical and soap manufacturers require a minimum titre of 40.5 to 41.0 . A titre of at least 40 is required for a tallow designation but it is not required to be 100 percent cattle fat.

Choice white grease (CWG) is derived primarily from 
pork tissue. The soap industry requires color specifications, but color is less important for feeding fats. Thus, considerable savings can often be acquired by developing feeding fat specifications that concentrate on the nutritional value of the respective fat.

Yellow grease (YG) has been a term used for a number of years and often confused with off-color CWG. Yellow grease is primarily restaurant grease/cooking oil sources but can contain other sources of rendered fat.

There are several documented benefits for use of animal fats in livestock, poultry, aquaculture, and companion animal diets including enhancing energy concentration of diets. Depending on the species to which it is being fed, the energy contributions of fat range from 2.6 to 3.8 times the energy content of corn. Energy values for the commonly used animal fats are listed in Table 5. In addition to the nutritional contribution, fat addition to animal diets contributes to dust control, reduced respiratory disease, feed mill cleanliness, worker comfort, improved palatability of feed, enhanced pelleting efficiencies, increased stability of fat soluble vitamins and other nutrients, and enhanced life of feed mixing and handling equipment.

Animal protein ingredients - Proteins are essential constituents of all biological organisms and are found in all body tissues of animals. Proteins are found in higher concentrations in organ and muscle tissue, and range from very insoluble types in feather, hair, wool, and hoofs, to highly soluble proteins such as those in serum or plasma. Animal derived foods are primary sources of protein and other nutrients in human diets. Similarly, the tissues from animal production and processing not utilized in human food are processed into an array of protein meals used in animal feeds.

AAFCO defines the composition of all legally used feed ingredients including rendered animal products. The 2006 AAFCO Ingredient Manualreferences some 125 individual animal by-products. The primary animal protein by-products

Table 5 - Energy values for fats commonly added to swine and poultry feeds ${ }^{1}$

\begin{tabular}{lcc}
\hline Fat Source & Poultry ME, kcal/lb & Swine ME, kcal/lb \\
\hline Yellow grease $^{3}$ & 3,582 & 3,663 \\
Poultry fat & 3,539 & 3,641 \\
Choice white grease & 3,424 & 3,585 \\
Brown grease & 3,332 & 3,534 \\
Tallow & 3,167 & 3,452 \\
Palm oil & 3,069 & 3,401 \\
\hline
\end{tabular}

${ }^{1}$ Calculated using equations from Wiseman et al. (1991) for poultry and Powles et al. (1995) for swine.

2 These equations calculate digestible energy (DE). Metabolizable energy (ME)

was calculated as 96 percent of DE.

${ }^{3}$ Recovered frying fat. are meat and bone meal (MBM), meat meal, blood meal, poultry by-product meal, poultry meal, feather meal, and fish meal. Using MBM as an example, AAFCO defines it as the rendered product from mammalian tissues including bone but exclusive of blood, hair, hoof, horn, hide trimmings, manure, and stomach and rumen contents. MBM as defined by AAFCO must contain a minimum of four percent phosphorus with a calcium level not to exceed 2.2 times the actual phosphorus level. Ingredients of lower phosphorus content must be labeled meat meal.

Meat and bone meal-In addition to the above AAFCO description, MBM shall contains not more than 12 percent pepsin indigestible residue and not more than nine percent of the crude protein shall be pepsin indigestible. Pepsin is a proteolytic enzyme which is secreted by the stomach where it hydrolyzes proteins to polypeptides and oligopeptides. If a protein is pepsin indigestible, animals are not able to digest it. MBM can be used in all species of livestock, poultry, and aquaculture, but only nonruminant source material must be utilized for ruminants (by FDA regulation).

Poultry by-product meal - Poultry by-product meal (PBM) consists of ground, rendered, clean parts of the carcass of slaughtered poultry such as necks, feet, undeveloped eggs and intestines, exclusive of feathers, except in the amounts as might occur unavoidably in good processing practices. The label shall include guarantees for minimum crude protein, minimum crude fiber, minimum phosphorus, and minimum and maximum calcium. The calcium level shall not exceed the actual level of phosphorus by more than 2.2 times. The quality of PBM, including critical amino acids, essential fatty acids, vitamins, and minerals along with its palatability, has led to its demand for use in pet foods and aquaculture.

Hydrolyzed Poultry Feather Meal (FeM)-Hydrolyzed poultry feather meal is pressure-cooked, clean undecomposed feathers from slaughtered poultry, free of additives and/or accelerators. Not less than 75 percent of its crude protein content must be digestible by the pepsin digestibility method. Modern processing methods that cook the feathers under pressure with live steam partially hydrolyze the protein and break the keratinaceous bonds that account for the unique structure of feather fibers. The resulting feather meal is a free flowing palatable product that is easily digested by all classes of livestock. Modern feather meals greatly exceed the minimum level of AAFCO required digestibility. 64 to 70 percent of its protein escapes degradation in the rumen and remains highly digestible in the intestinal tract. A specific characteristic is its excellent 
source of the sulfur containing amino acids, especially cystine.

Blood meal flash-dried - Blood meal flash-dried is produced from clean, fresh animal blood, exclusive of all extraneous material such as hair, stomach belchings, and urine, except as might occur unavoidably in good manufacturing processes. A large portion of the moisture (water) is usually removed by a mechanical dewatering process or by condensing by cooking to a semi-solid state. The semi-solid blood mass is then transferred to a rapid drying facility where the more tightly bound water is rapidly removed. The minimum biological activity of lysine shall be 80 percent.

Blood products are the richest source of both protein and the amino acid lysine as a natural ingredient available to the feed industry. Processing changes have altered the product considerably. In the past, its use was limited due primarily to vat-drying procedures that produced blood meal with poor palatability and low bioavailability of its lysine. Newer methods of processing (ring or flash-drying) produce a blood meal with digestibilities that routinely exceed 90 percent with acceptable palatability. The principal nutritional interest in blood meal is due to its high protein content and as an excellent source of lysine. Its properties as a high rumen bypass protein have been highlighted in research findings in dairy, feedlot, and range cattle.

Fish meal - Fish meal is generally considered in the animal protein class of ingredients though they are described in the marine products section of AAFCO. Fish meal is the clean, dried, ground tissue of decomposed whole fish or fish cuttings, either or both, with, or without the extraction of part of the oil. It must contain not more than 10 percent moisture. If it contains more than three percent salt, the amount of salt must constitute a part of the brand name, provided that in no case must the salt content of this product exceed seven percent.

Menhaden and anchovy are the main fish species used for meal manufacture, with lesser quantities of herring meal. With an increase in aquaculture directed at the human food industry, by-products from these processing sites are being utilized. Fish meal is usually an excellent source of essential amino acids and fat soluble vitamins. Digestibility of its amino acids is excellent, but as with other ingredients, highly correlated to processing. Fish meals can be used in all types of rations. In some products, such as companion food diets, the palatability factors and the taint (fishy smell and flavors) is a benefit. When used for other species, taint of eggs, milk, or meat can be a disadvantage.

Other products - There are several other specialty ingredients of animal protein origin such as plasma. Plasma in recent years has become a common component of early pig and calf formulas. Plasma is a highly digestible protein source in addition to providing immune response benefits in young animals.

Nutrient value of rendered proteins - The major animal protein ingredients, MBM, meat meal, and PBM,

Table 6 - Nutrient composition of animal proteins ${ }^{1}$

\begin{tabular}{lccc}
\hline Item & Meat and bone meal & Blood meal $^{2}$ & Feather meal \\
\hline Crude protein, \% & 50.4 & 88.9 & 81.0 \\
Fat, \% & 10.0 & 1.0 & 7.0 \\
Calcium, \% & 10.3 & 0.4 & 0.3 \\
Phosphorus, \% & 5.1 & 0.3 & 0.5 \\
TME $_{\mathrm{N}}, \mathrm{kcal} / \mathrm{kg}$ & $2,666^{3}$ & 3,625 & 3,276 \\
\hline
\end{tabular}

Amino acids, \%

\begin{tabular}{|c|c|c|c|c|}
\hline Methionine & 0.7 & 0.6 & 0.6 & 1.0 \\
\hline Cystine & 0.7 & 0.5 & 4.3 & 1.0 \\
\hline Lysine & 2.6 & 7.1 & 2.3 & 3.1 \\
\hline Threonine & 1.7 & 3.2 & 3.8 & 2.2 \\
\hline Isoleucine & 1.5 & 1.0 & 3.9 & 2.2 \\
\hline Valine & 2.4 & 7.3 & 5.9 & 9 \\
\hline Tryptophan & 0.3 & 1.3 & 0.6 & 0.4 \\
\hline Arginine & 3.3 & 3.6 & 5.6 & 3.9 \\
\hline Histidine & 1.0 & 3.5 & 0.9 & \\
\hline Leucine & 3.3 & 10.5 & 6.9 & 4.0 \\
\hline Phenylalanine & 1.8 & 5.7 & 3.9 & .3 \\
\hline Tyrosine & 1.2 & 2.1 & 2.5 & 1.7 \\
\hline Glycine & 6.7 & 4.6 & 6.1 & 6.2 \\
\hline Serine & 2.2 & 4.3 & 8.5 & 2.7 \\
\hline
\end{tabular}

${ }^{1}$ National Research Council (1994)

${ }^{2}$ Ring or flash-dried.

${ }^{3}$ Dale (1997), $\mathrm{TME}_{\mathrm{N}}=$ true metabolizable energy nitrogen corrected. 
are important feed ingredients for livestock, poultry, aquaculture, and companion animal diets throughout the world. These products contribute over two million tons of ingredients annually to the U.S. feed industry. In addition to protein, these meals are also excellent sources of essential amino acids, fat, essential fatty acids, minerals, and vitamins. The typical nutrient composition of the four most common animal proteins is shown in Table 6.

As can be noted, all of these ingredients are higher in protein than soybean meal and other plant proteins. In addition, MBM is higher in phosphorus, energy, iron, and zinc than soybean meal. The phosphorus level in MBM is seven-fold than that found in soybean meal and is in a form that is highly available to livestock and poultry. The phosphorus in both MBM and poultry meal is similar in bioavailability to feed-grade mono-dicalcium phosphate.

Individual suppliers of animal protein meals can often provide more detailed specifications than derived from published papers based on averages or dated analyses. Analytical precision for chemical and nutrient availability values in animal protein ingredients is improving (Parsons, et al., 1997). However, the most precise values have been derived from animal feeding studies.

Modern rendering processes, improved equipment, and computer monitored systems have resulted in significant improvements in the digestibility of animal proteins. Data collected from 1984 to the present demonstrate the digestibility improvements in the essential amino acids of lysine, threonine, tryptophan, and methionine. These data are summarized in Table 7.

Table 7 - Digestibility of meat and bone meal

\begin{tabular}{lcccccc}
\hline Amino acid & $1984^{\mathrm{a}}$ & $1989^{\mathrm{b}}$ & $1990^{\mathrm{c}}$ & $1992^{\mathrm{d}}$ & $1995^{\mathrm{e}}$ & $2001^{\mathrm{f}}$ \\
\hline Lysine, \% & 65 & 70 & 78 & 84 & 94 & 92 \\
Threonine, \% & 62 & 64 & 72 & 83 & 92 & 89 \\
Tryptophan, \% & - & 54 & 65 & 83 & - & 86 \\
Methionine, \% & 82 & - & 86 & 85 & 96 & 92 \\
Cystine, \% & - & - & - & 81 & 77 & 76 \\
\hline
\end{tabular}

a Jorgensen et al., 1984; ${ }^{\mathrm{b}}$ Knabe et al., 1989; ${ }^{\mathrm{c}}$ Batterham et al., $1990 ;{ }^{\mathrm{d}}$ Firman, 1992; ${ }^{\mathrm{e}}$ Parsons et al., 1997; ${ }^{\mathrm{f}}$ Pearl, 2001.
Lysine digestibility in high quality MBM improved from 65 percent to over 90 percent during this time period. Dramatic improvements in the digestibility of tryptophan and threonine have also been documented. Cystine digestibility is between 76 percent and 81 percent but values were not reported in studies conducted prior to 1992. Similar improvements in amino acid digestibility have occurred in poultry meal, feather meal, and especially in blood meal.

Competition - Rendered protein meals and fats compete with vegetable products on a daily basis. Shifts in usage, as well as new developments can change the business atmosphere in the future. One example is the development of the fast growing fuel ethanol industry. Currently, there are 97 ethanol plants in production, with an additional 33 ethanol plants under construction. These ethanol plants have an annual production capacity of 4.5 billion gallons (Renewable Fuels Association, August, 2006). Dry-grind ethanol plants represent the fastest growing segment of the fuel ethanol industry in the U.S., and produce the majority $(60 \%)$ of fuel ethanol. By-products from drygrind ethanol plants include wet and dry distiller's grains, wet and dried distiller's grains with solubles (DDGS), modified "wet cake" (a blend of wet and dry distiller's grains), and condensed distiller's solubles. Of these drygrind ethanol plant by-products, distiller's grains with solubles is the predominant by-product being marketed domestically (Shurson, 2005). Approximately 40\% of the distiller's grains with solubles is marketed as a wet byproduct for use in dairy operations and beef cattle feedlots. DDGS is marketed domestically and internationally for use in dairy, beef, swine, and poultry feeds. More than 15.4 billion pounds of DDGS was produced in the U.S. in 2005. Corn is the primary grain used in wet mills and dry-grind ethanol plants because of its high fermentable starch content compared to other feedstocks.

Shurson (2005) identified the following challenges facing DDGS in the animal feed marketplace: 1) Product identity and definition; 2) Variability in nutrient content, digestibility, and physical characteristics; 3) Lack of a quality grading system and sourcing; 4) Lack of standardized testing procedures; 5) Quality management and certification; 
Table 8 - Dry matter, energy, and fat composition of meat meal, dehulled soybean meal, and dried distiller's grains with solubles (DDGS)

\begin{tabular}{lccccc}
\hline Feedstuff & Dry matter, \% & Digestible energy, kcal/lb & Metabolizable energy, kcal/lb & Net energy, kcal/lb & Fat, \% \\
\hline Meat meal $^{\mathrm{a}}$ & 94 & 1,224 & 1,178 & 987 & 12.0 \\
Soybean meal & 90 & 1,673 & 1,535 & 917 & 3.0 \\
DDGS & 89 & 1,819 & 1,703 & 829 & 10.8 \\
\hline
\end{tabular}

a NRC, 1998.

${ }^{\mathrm{b}}$ University of Minnesota, http://www.ddgs.umn.edu/profiles.htm

Table 9 - Protein and amino acid composition of meat meal, dehulled soybean meal, and dried distiller's grains with solubles (\%)

\begin{tabular}{lcccccccc}
\hline Feedstuff & Protein & Lys & Thr & Trp & Met & Cys & Ile & Val \\
\hline Meat meal $^{\mathrm{a}}$ & 54.0 & 3.07 & 1.97 & 0.35 & 0.80 & 0.60 & 1.60 & 2.66 \\
Soybean meal $^{\mathrm{a}}$ & 47.5 & 3.02 & 1.85 & 0.65 & 0.67 & 0.74 & 2.16 & 2.27 \\
DDGS & 30.9 & 0.91 & 1.14 & 0.24 & 0.64 & 0.60 & 1.17 & 1.57 \\
\hline
\end{tabular}

a NRC, 1998

${ }^{b}$ University of Minnesota, http://www.ddgs.umn.edu/profiles.htm

6) Transportation; 7) Research, education, and technical Support; 8) International market challenges; 9) Lack of a national distiller's by-product organization and industry cooperation.

There is considerable variation in nutrient content and digestibility among DDGS sources compared to soybean meal (Shurson, 2005). Tables 8 and 9 compare the nutritional characteristics of DDGS to meat meal and soybean meal. Research shows that higher levels of DDGS in swine diets increases the amount of unsaturated fat and reduces fat firmness in pigs, which impacts the quality of the meat and consumer acceptance (Shurson, 2001). Meat quality concerns may limit the amount of DDGS that can be used in swine diets and the relatively high fiber content of DDGS may restrict its use in poultry diets. Also, since DDGS contains polyunsaturated fats, there are concerns about high levels in cattle diets that can result in the accumulation of unwanted trans-fats in meat animals and depressed milk fat production in dairy cows.

While the rendering industry is much more mature than the fuel ethanol industry in the U.S. and renderers have faced many of these same issues, and have solved some, it is instructive to keep an eye on the competition.

Future availability - The availability of rendered products for animal feeds in the future depends on regulation and the market. Renderers are innovative and competitive and will adapt to changes in both regulations and the market. Regulatory agencies will determine whether certain raw materials can be used for animal feed. Customer expectations, consumer demand, and economic considerations will dictate product specifications and prices.

\section{Literature Cited}

BATTERHAM, E.S.; ANDERSEN, L.M.; BAIGENT, D.R. et al. Utilization of ileal digestible amino acids by pigs: lysine. British Journal of Nutrition, v.64, p.679, 1990.

BEUMER, H.; VAN DER POEL, A.F.B. Effects on hygienic quality of feeds examined. Feedstuffs, v.69, p.13-15, 1997.

DALE, N. Metabolizable energy of meat and bone meal.Journal of Applied Poultry Research, v.6, p.169-173, 1997.

EUROPEAN COMMISSION. Trends and sources of zoonotic agents in the European Union and Norway. Health \& Consumer Protection Directorate-General Report on Salmonella, p.51-62, 2003.

FEDERAL REGISTER. Docket No. 2002N-0273. Substances prohibited from use in animal food or feed. 70:58570-58601, 2005.

FIRMAN, J.D. Amino acid digestibilities of soybean meal and meat meal in male and female turkeys of different ages. Journal of Applied Poultry Research, v.1, p.350-354, 1992.

HAMILTON, C.R. Real and perceived issues involving animal proteins. In: Protein sources for the animal feed industry. Expert Consultation and Workshop. Bangkok, April 29, 2002. Food and Agriculture Organization of the United Nations. Rome. p.255-276, 2004.

INFORMA ECONOMICS. An economic and environmental assessment of eliminating specified risk materials and cattle mortalities from existing markets. Prepared for National Renderers Association, 2004. p.5-10.

JORGENSON, H.; SAUER, W.C.; THACKER, P.A. Amino acid availabilities in soybean meal, sunflower meal, fish meal and meat and bone meal fed to growing pigs. Journal of Animal Science, v.58, p.926, 1984.

KNABE, D.A.; LA RUE, D.C.; GREGG, E.J. et al. Apparent digestibility of nitrogen and amino acids in protein feedstuffs by growing pigs. Journal of Animal Science, v.67, p.441-458, 1989.

McCHESNEY, D.G.; KAPLAN, G.; GARDNER, P. FDA survey determines Salmonella contamination. Feedstuffs, v.67, p.20-23, 1995.

NATIONAL RENDERERS ASSOCIATION. A buyer's guide to rendered products. Alexandria, VA, p. 15-16, 2003.

NATIONAL RESEARCH COUNCIL - NRC. Nutrient requirements of poultry. 9.ed. Washington, D.C.: National Academy Press, 1994. 
NATIONAL RESEARCH COUNCIL - NRC. Nutrient requirements of swine. 10.ed. Washington, D.C.: National Academy Press, 1998.

PARSONS, C.M; CASTANON, F.; HAN, Y. Protein and amino acid quality of meat and bone meal. Journal of Poultry Science, v.76, p.361-368, 1997.

PEARL, G.G. Proceedings of Midwest Swine Nutrition Conference. Indianapolis, IN, 2001.

POWLES, J.; WISEMAN, J. COLE, D.J.A. et al. Prediction of the apparent digestible energy value of fats given to pigs. Journal of Animal Science, v.61, p.149-154, 1995.

SHURSON, G.C. Overview of swine nutrition research on the value and application of distiller's dried grains with solubles produced by Minnesota and South Dakota ethanol plants. Department of Animal Science, University of Minnesota, St. Paul, 2001.
SHURSON, G.C. Issues and opportunities related to the production and marketing of ethanol by-products. USDA Ag Market Outlook Forum, Arlington, VA, p.1-8, 2005.

SREENIVAS, P.T. Salmonella - control strategies for the feed industry. Feed Mix, v.6, p.5-8, 1998.

TAYLOR, D.M.; WOODGATE, S.L.; ATKINSON, M.J. Inactivation of the bovine spongiform encephalopathy agent by rendering procedures. Veterinary Record, v.137, p.605$610,1995$.

TROUTT, H.F.; SCHAEFFER, D.; KAKOMA, I. et al.Prevalence of selected foodborne pathogens in final rendered products. Fats and Proteins Research Foundation (FPRF), Directors Digest \#312. Alexandria, VA, 2001.

WISEMAN, J.F.; SALVADOR, F.; CRAIGON, J. Prediction of the apparent metabolizable energy content of fats fed to broiler chickens. Journal of Poultry Science, v.70, p.1527-1533, 1991. 